\title{
“MEMBACA ZAMAN": REFLEKSI PEMIKIRAN JEIHAN DALAM LUKISANNYA, 1953-2012
}

\author{
Herliyana Rosalinda ${ }^{*}$, Dhanang Respati Puguh ${ }^{2}$ \\ ${ }^{*}$ Fakultas Bahasa dan Seni Universitas Indraprasta PGRI \\ ${ }^{2}$ Departemen Sejarah Fakultas Ilmu Budaya Universitas Diponegoro \\ Alamat korespondensi: herliyanarosalinda1990@gmail.com
}

Diterima/ Received: 9 Desember 2016; Disetujui/ Accepted: 24 Februari 2017

\begin{abstract}
This research examines on the reflection of Jeihan's thought traced via his paintings produced during 1953 until 2012. It uses historical method with hermeneutical approach. Jeihan's childhood experienced abnormalities, that made him marginalized in his family and social environment. As the result, his personality became rough and rebellious. It affected his painting style that tend to be harsh and had no character. This bad temper attached him until 1953, when Jeihan studied painting in Himpunan Budaya Surakarta (HBS), and continued his higher education to Institut Teknologi Bandung (ITB). In order to understand painting style, it can be seen from line and color paintings that always progressed. It can be analyzed into four periods which colored by a different artistic style, that are seeking (1952-1965), discovery (1965-1975), maturation (1975-1985), and reaping period (1986-2012).
\end{abstract}

Keywords: Jeihan Sukmantoro; Paintings; Interpretation; Artworks

\begin{abstract}
Abstrak
Penelitian ini mengaji refleksi pemikiran Jeihan melalui lukisannya dalam periode 1953-2012, yang menggunakan metode sejarah dengan pendekatan hermeneutika. Masa kecil Jeihan mengalami situasi yang tidak normal yang menyebabkan dirinya termarjinalisasi, baik dalam lingkungan keluarga maupun sosialnya. Akibatnya, Jeihan mempunyai kepribadian yang keras dan pemberontak. Hal ini memengaruhi gaya lukisannya, yakni cenderung kasar dan belum menemukan ciri khas. Sifat buruknya ini terus dibawa ketika pada 1953, ia belajar seni lukis di Himpunan Budaya Surakarta (HBS), dan berlanjut masa perkuliahan di Institut Teknologi Bandung (ITB). Untuk memahami corak lukisannya, dapat dilihat dari penggunaan garis dan warna lukisan yang selalu berkembang. Perkembangan itu dapat dilihat dari setiap periode kesenimanannya yang terbagi dalam empat fase, yaitu Fase Pencarian (19521965), Fase Penemuan (1965-1975), Fase Pematangan (1975-1985), dan Fase Pemetikan (1986-2012).
\end{abstract}

Kata Kunci: Jeihan Sukmantoro; Lukisan; Penafsiran; Karya seni

\section{PENDAHULUAN}

Seni lukis merupakan salah satu bentuk ungkapan seniman dalam mengekspresikan berbagai makna yang tertuang dalam lukisan. Makna yang diekspresikan pelukis dalam karya lukisannya tidak terlepas dari karakteristik seniman. Perbedaan karakter memengaruhi kemampuan seorang seniman yang sekaligus mendasari setiap pelukis memiliki temperamen yang berbeda-beda. Kemampuan inilah yang membedakan individu pelukis yang tidak terlepas dari pembahasan mengenai self (diri). Diri adalah suatu bentuk keberadaan manusia, sebagai perwujudan meng-ada-nya dalam sebuah kehidupan. Dalam hal ini, gaya hidup seseorang 
tidak dapat dilepaskan dari diri yang meng-ada dan eksis dalam gaya hidup tersebut. Oleh karena itu, ekspresi pelukis dalam sebuah lukisan didasari oleh pengaruh dari gaya hidup pelukis tersebut. Hal ini juga berlaku pada diri Jeihan, pelukis Indonesia yang tetap eksis dalam dunia seni lukis sejak awal kariernya.

Jeihan dikenal sebagai pelukis figuratif. Lukisan karya Jeihan, sebagian besar adalah lukisan manusia, dan manusia yang dilukis oleh Jeihan mereprentasikan ekspresi batinnya terhadap gaya kehidupannya. Baik di Indonesia maupun di mancanegara sangat banyak pelukis figuratif manusia yang saling bersaing, antara lain adalah pelukis Trubus, Basuki Abdullah, Sudarso, dan Dullah. Persaingan yang terjadi tersebut dilatarbelakangi oleh konvensi umum, bahwa melukis manusia adalah dunia seni lukis akademis. Persaingan ketat di wilayah seni lukis figuratif manusia menjadi semacam gejala yang tidak pernah selesai. Tampaknya, Jeihan mampu bersaing dengan pelukis figuratif lainnya. Pada 1963, Ia mengambil keputusan berani untuk menghitamkan seluruh bagian mata modelnya. Hal ini selanjutnya disebut dengan istilah mata bolong. Penciptaan lukisan figuratif bermata bolong menjadi ciri atau spesifikasi yang khas bagi lukisan Jeihan pada masa-masa berikutnya.

Sebagai pelukis figuratif, tidak banyak masyarakat yang paham bahwa Jeihan juga memiliki terobosan-terobosan pemikiran dalam lukisannya yang bersifat humanis dan spiritual. Penelitian ini berusaha untuk mengungkap pemikiran Jeihan yang tertuang dalam lukisannya yang mempunyai kekhasan atau keunikan sendiri dilihat dari diksi visual. Lewat pemahaman itulah, refleksi dari pemikiran Jeihan dari periode 1953 sampai dengan 2012 menjadi perhatian utama penelitian ini.

\section{METODE}

Kajian ini dilakukan dengan menggunakan metode sejarah yang mencakup empat tahapan, yaitu heuristik, kritik sumber, interpretasi fakta, dan rekonstruksi. Sumber primer yang dikumpulkan dalam penelitian berupa lukisan Jeihan yang dapat dibaca seperti sebuah teks yang dapat menceritakan gagasan pembuatnya.
Selain itu, penulis menggunakan sumber tertulis berupa artikel dalam media massa cetak, artikel online, hasil-hasil kajian tentang Jeihan dan karya-karyanya. Sumber-sumber tertulis ini memuat berbagai fakta antara lain mengenai kisah hidup, pandangan spiritual, karya-karya, pameran yang diikuti, dan pandangan kurator atau kritikus seni terhadap lukisan-lukisannya yang ditulis sezaman dengan peristiwa tersebut, sehingga ada kemungkinan besar sumber ini merupakan sumber yang otentik.

Selain itu, dalam penelitian ini digunakan sumber lisan yang diperoleh melalui wawancara dengan Jeihan sebagai pelaku utama, dan Atasi Amin, anak pertama Jeihan yang mengurusi karier dan keperluan Jeihan serta sekaligus menjadi Humas di Studio Jeihan. Wawancara juga dilakukan dengan Andi, sebagai sopir pribadi Jeihan sejak 1980-an. Wawancara dilakukan untuk mendapatkan informasi tentang sosok kepribadian Jeihan di mata kalangan umum.

Selanjutnya dilakukan kritik eksteren dan interen. Sebagai contoh adalah laporan tentang proses pembuatan lukisan yang berjudul "Mimi Rasinah" yang dibuat pada 11 Januari 2004 oleh Jeihan. Laporan itu merupakan sumber asli, karena masih dalam bentuk sebagaimana yang disusun oleh wartawan dan menyajikan informasi paling awal tentang kegiatan itu. Kritik interen bertujuan untuk mendapatkan fakta-fakta yang dapat dipercaya. Kritik ini dilakukan terutama terhadap laporan media massa cetak dan online. Publikasi yang luas juga merupakan kondisi yang menguntungkan kredibilitas karena dapat memperkecil peluang untuk menyampaikan kebohongan.

Langkah berikutnya adalah interpretasi fakta dengan menyeleksi, menyusun, memberi atau mengurangi penekanan, dan menata faktafakta ke dalam urutan tertentu. Seleksi fakta dilakukan dengan memilih fakta-fakta yang relevan dengan topik kajian dan kemudian menghadapkannya pada pertanyaan-pertanyaan penelitian serta kerangka teoretis yang telah dibangun.

Fakta-fakta yang telah diseleksi selanjutnya diorganisasikan secara tematis 
dengan mengikuti alur proses penafsiran dalam hermeunitika geisteswissenschaften, yang memfokuskan pada pemahaman seni, aksi, dan tulisan manusia. Selanjutnya dilakukan penulisan sejarah. Rekonstruksi diarahkan untuk menyajikan deskripsi tentang peristiwa dan proses yang ingin dikaji. Deskripsi tentang peristiwa berkenaan dengan usaha untuk menjawab pertanyaan apa, siapa, kapan, dan di mana; sedangkan deskripsi tentang proses bertujuan untuk menjawab pertanyaan mengapa, bagaimana, dan apa jadinya.

\section{KISAH HIDUP JEIHAN}

Jeihan Sukmantoro merupakan nama lengkap Jeihan. Ia adalah anak ke empat dari enam bersaudara yang lahir pada 26 September 1938 dari pasangan Widiatmo dan Mari, di Desa Ampel atau Ngampel yang terletak di kaki Gunung Merbabu Boyolali Jawa Tengah. Ayah Jeihan merupakan keturunan raja-raja Surakarta, sedangkan ibunya adalah keturunan Cina yang berasal dari Demak (Mahatma, 2010: 65).

Pada masa kecil, Jeihan termasuk anak yang kurang mendapatkan kasih sayang dari orang tuanya, karena ia lebih sering diasuh oleh pembantunya. Hal ini karena orang tua Jeihan menginginkan kehidupan anaknya serba kecukupan dan bahagia. Selain itu, Jeihan juga terpaksa dipisahkan dari orang tuanya dan diasuh oleh saudara ibunya yang lebih profesional dalam mendidik anak. Maksudnya, agar pendidikan Jeihan menjadi lebih terjamin. Orang tua Jeihan berpikir, bahwa mereka yang terlatih dalam pendidikan anak akan lebih baik mendidik anak. Namun cara orang tua ini belum tentu sama dengan cara berpikir anak mengenai pencapaian kebahagiaan. Dari sinilah konflik keluarga sering muncul, dan anak tersebut terjerumus pada ketidakbahagiaan.

Jeihan kecil juga pernah mengalami kecelakaan. Ia jatuh dari tangga yang mengakibatkan salah satu tulang lehernya patah dan berakibat pada gangguan otak dan epilepsi (Mamannoor, 2005: 46). Kecelakaan tersebut terjadi di Boyolali. Saat itu zaman pendudukan Jepang (1942), sehingga pertolongan medis sangat terbatas. Ia dirawat di Rumah Sakit
Surakarta, dan divonis oleh dokter tidak dapat meneruskan sekolah, karena dapat membahayakan dirinya. Ia harus mengistirahatkan otaknya selama empat belas tahun (Sumardjo, 2007: 123).

Ketika Jeihan berusia belasan tahun, waktunya banyak dihabiskan hanya untuk menggambar dan belajar melukis di Himpunan Budaya Surakarta (HBS) sampai 1956. HBS sendiri adalah organisasi pertama yang berdiri di Surakarta sebagai wadah pembelajaran dan pengapresiasian bagi seniman-seniman muda di Surakarta, yang terdiri dari cabang seni pedhalangan, seni lukis, seni tatah ukir, seni bela diri, seni gamelan, dan seni tari yang masingmasing dikelola dengan baik (Mekar Sari, 1987: 29).

Jeihan baru masuk sekolah formal ketika usianya empat belas tahun setelah masa istirahatnya dari sakit yang dideritanya berakhir. Pada masa prasekolah, tentu saja Jeihan tidak banyak mengenal bahasa-bahasa huruf. Jeihan lebih fasih bahasa-bahasa gambar daripada berbahasa dengan huruf-huruf. Namun hal itu tidak menyurutkan semangatnya dalam belajar.

Meskipun tidak sekolah, Jeihan belajar membaca dan menulis huruf-huruf Latin sendiri. Jeihan juga menguasai huruf-huruf Jawa. Karena tidak mungkin memulai dari dasar, maka Jeihan bertekad masuk SMP. Meski demikian yang bisa menerima dia sebagai murid hanya SMP extension yang tidak menerapkan ujian kelaskelas reguler. Jeihan tercatat sebagai siswa nakal. Ia sering membolos dan mengajak temantemannya untuk ikut bolos saat guru yang sekiranya ia anggap "bodoh" sedang mengajar.

Setelah lulus dari SMP persamaan itu, Jeihan mendaftarkan diri di sebuah SMA Katholik Surakarta dan di SMA Negeri III Margoyudan. Pengumuman siswa baru terlebih dahulu keluar dari SMA Katholik tersebut. Jeihan mendaftarkan diri sebagai murid. Mendengar Jeihan masuk sekolah Katholik, kepala sekolah Kristen Filialnya memanggil Jeihan. Ia bertanya pada Jeihan, mengapa tidak masuk SMA Kristen, tetapi masuk SMA Katholik, Jeihan menjawab: "Tuhan mengetahui mana yang terbaik, Pak". Saat itu (1950-an), perseteruan diam-diam antara Katholik dan 
Kristen Protestan memang cukup keras. Tidak mengherankan apabila Jeihan yang lulusan SMP Kristen memasuki SMA Katholik sebagai suatu "penghianatan", meskipun kepala sekolah tahu bahwa Jeihan sama sekali bukan orang Kristen (Mamannoor, 2007: 13).

Sebelum SMA Katholik memulai pelajarannya, SMA Negeri memanggil Jeihan untuk diterima sebagai siswanya. Dengan segera Jeihan pindah ke SMA Negeri III. Pada awalnya Jeihan tercatat sebagai siswa baik, namun bakat nakalnya mulai kambuh kembali setelah duduk di bangku kelas dua. Seperti biasa, ia membolos dengan mengajak teman-temannya dan mendapat skors dilarang masuk beberapa hari oleh kepala sekolahnya yang bernama Bapak Paryatmo. Sangat banyak catatan kenakalan Jeihan, namun ia juga aktif dalam kegiatan ekstrakulikuler sekolah terutama di bidang seni, baik lukis, sastra, maupun teater. Ia sering menjadi koordinator melukis untuk temanteman sekolahnya. Jeihan juga menjadi sutradara teater, serta memimpin majalah dinding di sekolahnya. Sajak-sajak Sapardi Djoko Damono banyak dimuat Jeihan di majalah dindingnya. Jeihan sering menggoda Sapardi dengan menuliskan nama Sapardi menjadi Supardi Djoko Damono (Mahatma, 2010: 69). Kedekatan keduanya dapat dilihat pada Gambar 1.

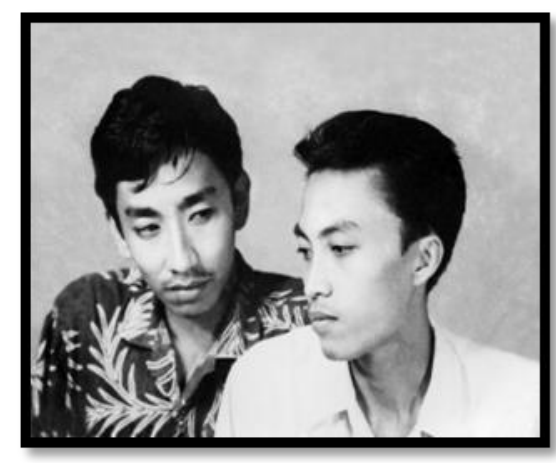

Gambar 1. Jeihan dan Sapardi Djoko Damono masa SMA

Sumber: Koleksi Atasi Amin, Studio Jeihan.

\section{Pola Pemikiran Kesenimanan Jeihan}

Berdasar perjalanan hidupnya, Jeihan memiliki cara pandang yang dibuat sebagai jalan berpikirnya terhadap kesenimanannya serta gerak membaca zaman, yang diartikan sebagai proses pembelajaran dan bertahan untuk menghadapi masa depan. Jeihan memilih jalan spiritual sebagai cara pandangnya. Spiritualitas Jeihan diletakkan pada dua unsur, yaitu unsur keislaman dan kejawen. Keduanya berjalan berdampingan dan seimbang dalam kehidupannya.

Masa kecil adalah titik awal pembentukan pola pemikiran Jeihan. Berawal dari masa kecilnya, Jeihan ditempatkan pada dua arah pemikiran yang berbeda. Antara unsur spiritual dan rasional, kemudian berkembang menjadi minatnya terhadap budaya Indonesia dan unsur keislaman, hingga terciptanya identitas sebagai pelukis dan penyair. Semua itu didasari oleh pemahamannya terhadap harmoni kehidupan, bahwa hidup harus seimbang demi tercapainya kebaikan.

Budaya Jawa yang kental dengan nilai-nilai spiritual dipadukan dengan Barat yang lebih mengedepankan analitik. Rasionalitas Jeihan yang tajam dan maskulin ini diperoleh dari ibunya, sementara spiritualnya yang penuh misteri, feminim, dan penuh rasa sayang, justru diperoleh dari ayahnya. Adapun sifat dasar Jeihan tampaknya adalah 'menolak'. Mungkin pula adalah 'pemberontakan', seperti yang terungkap dalam ucapannya, "Jangan mengutip, jangan percaya terhadap teori orang, buatlah teorimu sendiri" (Wawancara dengan Jeihan pada 17 September 2012). Riwayat penolakan Jeihan adalah riwayat penolakan asal usulnya sendiri. Masa kecil yang tidak merasa bahagia, penuh kekangan, penyakit, dan kurang kasih sayang dari orang tua menandakan bahwa sejak semula ia ditempatkan pada posisi menolak.

Jeihan mulai masuk Institut Teknologi Bandung (ITB) dengan membawa sifat-sifat bawaannya yang selalu menolak itu. Ia membutuhkan ITB, tetapi juga menolak ITB. Akibatnya Jeihan menjadi antagonis di lingkungannya. Ia selalu tidak sepaham dengan pemikiran akademis. ITB penting bagi riwayat kesenimanan Jeihan. Ia belajar di Fakultas Seni Rupa dan Desain (FSRD) ITB dari 1960 sampai 1966. Jeihan tidak ingin masuk Akademi Seni Rupa Indonesia (ASRI) di Yogyakarta yang dekat dengan rumahnya di Surakarta, karena masih satu habitat dengan HBS yang pernah 
diikutinya, dan menurutnya masuk ITB lebih menjanjikan. Praktis alamiah seni rupa yang berasal dari lingkungannya sudah ia kuasai, dan Jeihan ingin memadukannya dengan rasionalitas Barat yang ada di ITB (Tambayong, 2012: 151).

Pendidikan gaya Barat memperkenalkan pola berpikir rasional yang pada praktik seni rupanya membentuk laboratorium Barat. Kemudian ITB dikenal sebagai "laboratorium Barat", atau "laboratorium kebarat-baratan", karena dulu sebagian besar dikelola oleh nasionalis Indonesia yang menerima pelatihan. ITB juga telah mempertahankan warisan dan pengaruh pengajar dari Belanda. Maka dari itu, pelajarannya disusun ke Barat yang memperkenalkan aliran abstrak. Hal ini membuat ITB terlihat individual, karena bertentangan dengan nasionalisme yang sedang diperjuangkan rakyat Indonesia (Supangat, 2000: 12).

Jeihan menyadari bahwa perbedaan itu ada, tetapi hal itu tidak membuatnya mengikuti pola Barat yang menumbuhkan aliran abstrak, atau pun menentang pola pemikiran figuratif kerakyatan. Ia menyadari bahwa baik abstrak maupun figuratif, keduanya sama-sama baik dan selaras pada kehidupannya. Ia memang suka mempelajari alam pikir Barat dan alam batin Timur yang dianggap berguna untuk keseimbangan hidup. Menurut Jeihan pikiran Barat seperti matahari dan batin Timur laksana rembulan. Jadi, keduanya saling menunjang dan sama-sama penting (Mustika, 1993: 56).

Aliran figuratif menjadi identitas Jeihan, meskipun ia berasal dari ITB yang merupakan pusat aliran abstrak. Hal ini didasari pada kecintaan dan kepeduliaannya dengan kemanusiaan. Jeihan senang memelajari berbagai macam karakter manusia, khususnya karakter orang Indonesia dan terlebih lagi pada perempuan. Dalam suatu kesempatan pada 1960-an diadakan pameran bersama, yaitu mahasiswa ITB dan ASRI. Pihak Yogyakarta menganggap bahwa lukisan Jeihan bergaya Bandung (ITB), sebaliknya pihak Bandung menganggap lukisan Jeihan bergaya Yogyakarta (ASRI). Padahal, menurut Jeihan, lukisan karyanya, tidak bergaya Bandung dan tidak pula bergaya Yogyakarta. Keadaan ini menjadi salah satu pemicu keputusan Jeihan untuk keluar dari ITB dengan keinginan untuk menjadi diri sendiri.

Jeihan lebih banyak menghasilkan lukisan perempuan. Bagi Jeihan, perempuan adalah makhluk yang penuh misteri. Hal ini didasari oleh pengalaman hidupnya di masa kecil. Ada sosok perempuan yang selalu merawatnya, memberikan kasih sayang dan mengasuhnya, namun sosok ini bukanlah ibunya, melainkan pembantu-pembantu di rumah Jeihan. Pembantu-pembantu ini bukan dari golongan yang terpelajar, bukan merupakan manusia yang memiliki kedudukan tinggi, namun nilai etika dan ketulusan dalam mengasuh Jeihan selalu ditampilkan oleh para pembantunya itu. Kekaguman Jeihan terhadap perempuan telah mendorongnya untuk selalu mempelajari hal-hal tersebut. Sementara ibu kandung yang ia harapkan memberikan kasih sayang, justru meninggalkannya. Dalam diri Jeihan ada perasaan antara benci dan cinta, benci kepada ibunya yang meninggalkannya, kemudian ada perasaan kagum pada sosok pembantunya yang tulus memberi cinta kepadanya, walaupun tidak ada hubungan darah di antara mereka (Wawancara dengan Jeihan pada 17 September 2012).

Ketika mulai membuat lukisan, Jeihan ingin menggambarkan sosok figur perempuan yang lekat pada kehidupannya saat kecil, ada pula ekspresi dari dalam dirinya sendiri atas penderitaan di masa lalu. Ada unsur kesederhanaan di dalam lukisannya, yang mengarah ke bentuk feminin. Secara visual, lukisan ini digambarkan dengan raut wajah perempuan yang selalu tampak senyap. Dalam posisi mengambang, perempuan-perempuan itu seolah mempertanyakan eksistensi diri mereka sendiri. Perempuan-perempuan tadi 'diciptakan' Jeihan ketika dalam keadaan yang tidak bergerak sesentipun. Mereka diminta berpose kemudian dengan leluasa Jeihan memindahkan kondisi itu, tentu saja disertai interpretasi, ke atas kanvasnya (Kompas, 18 Januari 2004). Sebagian besar lukisan perempuan karya Jeihan menampilkan figur perempuan dewasa, remaja, dan anak-anak. Figur-figur manusia yang dilukisnya selalu berdasar pada model. Karena melukis 
berdasarkan model, dan sebagian besar lukisannya dikerjakan di Bandung, maka yang banyak ia lukis adalah perempuan-perempuan Sunda. Perempuan-perempuan dalam lukisan Jeihan rata-rata terlihat kurus ramping dan berwajah manis. Jarang lukisan perempuannya yang montok. Model yang dipilih oleh Jeihan bukan didasarakan pada kecantikan, tetapi keunikannya (Sumardjo, 2007: 353).

Modelnya adalah rakyat kecil dari daerah perkampungan atau dari penduduk di sekitar kediamannya. Mereka yang menjadi model terlihat kurus, sehat, lugu, santai, dan tampak tanpa ekspresi. Tidak ada kepalsuan, begitulah model-model Jeihan, ketika ia bermukim di kawasan Cidadas, Bandung yang padat penduduk. Perempuan yang menjadi modelnya, adalah para wanita yang tinggal di kawasan Cidadas itu. Ia mengenal perempuan yang dilukisnya itu satu per satu. Potret perempuanperempuan Cicadas itu terlihat dengan jelas pada lukisan-lukisannya periode 1970 -an

Selain itu, Jeihan juga memproduksi lukisan "Nude", karena lukisan semacam ini laku. Tidak ada peraturan negara yang melarang melukis dan memiliki lukisan perempuan telanjang, bahkan dalam pameran lukisan tidak dilarang. Lukisan-lukisan "Nude" Jeihan tidak mengarah pada sensasi tubuh perempuan telanjang dan tidak sampai menjangkau alat vital. Telanjang hanya sebagai ekspresi batin tokohnya. Di balik ketelanjangan seorang perempuan dalam "Nude", ada kerapuhan manusia yang hanya dilihat dalam telanjang tubuhnya. Lukisan-lukisan "Nude" Jeihan merupakan tanggapan praksis hidup masyarakat, hanya saja objeknya adalah tubuh perempuan.

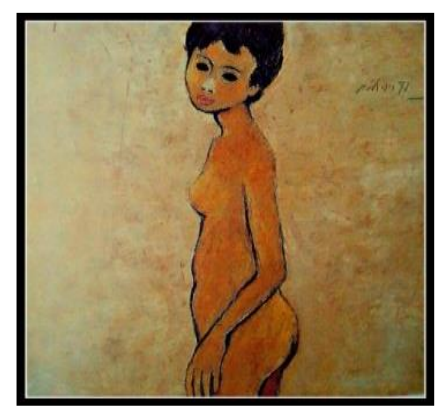

Gambar 2. Lukisan "Nude"

(Dokumentasi Peneliti, 2015)
Pilihan model "Nude" Jeihan merupakan perempuan-perempuan urban, yaitu perempuan desa yang hidup di kota. Hasil lukisan ini terlihat pada lukisan Jeihan berjudul "Nude" yang dibuat pada 1977, jauh dari bayangan wanita telanjang dalam pose mempesonakan (Jeihan, 1993: 21).

Lukisan ini menampilkan perempuan berwajah remaja, berdiri lurus di tengah bidang lukisan. Ia tidak berpose sama sekali dan tidak menampilkan ketelanjangannya. Wajahnya menoleh. Ia berdiri dengan posisi menyamping memancarkan ekspresi naif, dan tidak merasa ketelanjangannya sebagai hal yang luar biasa. Perempuan itu tidak tegang, tidak malu, dan terutama tidak memancing perhatian. Tangannya yang terkulai di sisi tubuh, tidak menandakan gerak yang sengaja menutup bagian-bagian tubuh. Lukisan "Nude" karya Jeihan tidak hanya memperlihatkan ekspresi ketelanjangan sebagai fenomena yang sangat biasa, tetapi juga menunjukkan penafsiran Jeihan tentang wanita telanjang. Justru karena tekanan dan penafsiran itu, orang mampu menangkap fenomena ketelanjangan yang tidak biasa, yakni Jeihan mempunyai citra yang tidak mengekspose tentang wanita telanjang.

Periode lukisan telanjang Jeihan terjadi pada masa kuliah di ITB. Pada saat itu ada salah satu mata kuliah yang mengharuskan mahasiswanya melukis "Nude". Setelah mengalami proses kehidupan yang berganti dan pemikiran Jeihan menjadi lebih spiritual, modelmodel lukisannya banyak yang mengenakan jilbab atau terbungkus rapat. Gaya lukisannya ini, terutama akan terlihat pada awal tahun 1950-an hingga 2012.

Sekitar tahun 1953, ketika masih tinggal di Surakarta dan berlatih melukis di HBS, ia melukis model dan potret diri dengan bentuk mata biasa seperti pelukis lainnya bila membuat mata, yakni ada warna putih yang mengelilingi bola mata yang berwarna hitam. Perhatian utama dalam melukis sosok manusia diakuinya pada bagian mata, baik model anak-anak, orang tua, lelaki, dan khususnya perempuan. Semua bagian tubuh dapat dilukiskan dengan baik, melukis kepala, membuat telinga, hidung, bibir, wajah terlebih lagi dapat dikuasainya dengan baik. 
Akan tetapi, begitu tiba pada bagian mata, ia merasa selalu mengalami kesulitan. Meskipun selesai namun tidak sesuai dengan mata yang ingin ia ekspresikan dan tidak sesuai dengan perasaannya. Peristiwa seperti ini dialaminya terus menerus hingga saat ia pindah ke Bandung untuk melanjutkan pendidikan seni lukis di ITB. Dapat dikatakan bahwa selama 10 tahun seluruh karya Jeihan khususnya bagian mata pada awalnya adalah suatu kegagalan. Artinya, bentuk mata dibuatnya seperti biasa, yakni terdapat kornea putih dan bola mata yang hitam. Selama itu pula bentuk mata diselesaikan tanpa ketepatan dengan ekspresi tuntutan jiwanya saat itu.

Antara mencari dan menemukan "roh" mata, bagi Jeihan bagaikan gerakan reflek tangan kanannya dalam melepaskan pisau palet berganti dengan warna biru tua, dan langsung ditorehkan pada bidang mata yang berwarna putih. Mata yang putih secara tidak sadar telah tertutup dengan warna biru tua pun menyatu dengan bola mata yang hitam. Sesuatu yang telah terjadi, cepat bagaikan kilat, mata potret dirinya sendiri telah berubah menjadi dua cercah lubang dalam yang gelap. Dalam waktu yang hampir bersamaan Jeihan merasakan suka cita dalam jiwanya, kegelisahan batinnya bagaikan diam tentram; terasa sesuatu yang dicari puluhan tahun yang lalu telah ditemukan kini, yaitu dua lubang mata warna hitam yang gelap sekali namun telah menentramkan batinnya (Mustika, 1993: 56).

Sekitar tahun 1963 Jeihan memunculkan ungkapan baru dalam seni lukis dengan menghitamkan objek mata dalam setiap figur yang ia lukis yang ia rasakan telah sesuai jiwanya. Ia mengatakan: "biarlah setiap mata lukisanku hanya lubang hitam gelap, namun rasanya dapat melihat, dan itu pas, persis, cocok sekali dengan mata tuntutan rohku". Demikian proses Jeihan menemukan "mata bolong" yang telah berlanjut hingga saat ini bahkan tidak terbatas pada objek manusia belaka, namun berlaku pula bagi objek binatangnya. Pada buku yang ditulis oleh Mustika yang terbit pada 1993, Jeihan mengatakan: "Pada akhirnya walaupun manusia mempunyai mata yang bagus, toh tak mengetahui dengan persis hakikat dirinya sendiri”.

Pemikiran Jeihan berkembang saat ia telah mengalami fase kehidupan yang serba kecukupan pada 2000-an. Saat mengadakan percakapan dengan penulis, Jeihan mengungkapkan pemikirannya, bahwa filosofi mata bolong ini menurutnya adalah "manusia itu selalu berjalan di tengah kegelapan, artinya kita tidak pernah mengetahui apa yang akan terjadi di masa depan". Di sisi lain, ia berkata, bahwa: "efek global warming akan semakin parah. Hal itu mengakibatkan sinar matahari yang mengandung Ultra Violet (UV) akan masuk secara bebas dan berbahaya bagi manusia, sinar itu akan merusak mata, dan pada hakikatnya manusia harus mamakai pelindung mata berupa soft lense berwarna hitam untuk mencegahnya. Fenomena itu sudah saya tangkap, lewat lukisan saya" (Wawancara dengan Jeihan pada 17 September 2012).

Dengan adanya inovasi ini Jeihan membuktikan bahwa sebagai seorang pelukis harus mampu berpikir jauh ke depan, dalam arti mampu membaca gerak zaman. Ia menjadi dirinya sendiri dan bukan menjadi pengekor.

\section{Fase-fase Kesenimanan}

Periodisasi kesenimanan Jeihan terdiri atas empat fase, yaitu fase pencarian pada 19501965 , fase penemuan format khasnya pada 1966 1975, fase pematangan dimulai pada 1976-1985, dan fase pemetikan pada 1986-2012. Pembagian fase ini dilihat dari awal perjalanan karier Jeihan sebagai pelukis hingga menjadi pelukis terkenal.

\section{Fase Pencarian (1953-1965)}

Periode 1952-1965 merupakan fase pencarian yang ditandai dengan Jeihan mulai masuk ke HBS pada 1952 hingga 1956. Saat itu Jeihan belum duduk di bangku sekolah formal, ia lebih dahulu mengenal lukisan dibanding mengenal pelajaran. Di HBS merupakan titik awal pembelajaran Jeihan terhadap seni, khususnya seni lukis. Meskipun Jeihan banyak menyaksikan dan belajar kesenian Jawa, seni lukis menjadi pusat perhatian pembelajaran Jeihan. Namun 
kemudian Jeihan juga belajar seni tatah ukir atau cukilan kayu.

Jeihan mulai banyak menghasilkan lukisan pada 1953. Corak lukisannya lekat dengan aliran realisme kerakyatan yang berkembang di HBS saat itu. Lukisan tersebut di antaranya adalah lukisan yang berjudul "Perempuan Tua", "Unknown Woman", dan "Anak Kecil”. Kemudian pada 1956 Jeihan melukis "Aku". Karya-karya tersebut membicarakan tentang objek. Objek yang ada pada lukisannya masih menampilkan sosok yang ada di sekitar kehidupan masyarakat dengan ekspresi yang natural. Sampai di sini Jeihan belum menemukan sikap dan gaya yang khas.

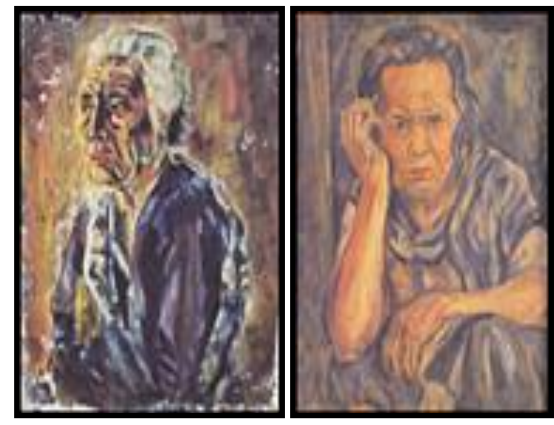

Gambar 3. Lukisan "Perempuan Tua" (kiri) dan Lukisan "Unknown Woman" (kanan) Sumber: Dokumentasi Peneliti, 2012.

Pada 1960, Lekra mendorong Presiden Soekarno untuk melarang menggambar abstrak (Supartono, 2000: 40). Dengan adanya larangan dari Presiden Soekarno, mahasiswa ITB juga ikut menggambar dengan aliran realisme sosialis. Biasanya Jeihan menggambar semirealis yang tampak pada lukisan-lukisan figuratifnya. Namun kali ini ia menggambar abstrak dan mengirimkan vignetnya ke majalah Basis di Yogyakarta. Gaya abstrak tersebut menular ke teman-teman kuliahnya. Ia mendapat banyak kritik dari dosennya, sehingga Jeihan dituduh mendirikan 'sanggar' di kampusnya.

Bentuk perlawanan Jeihan dipertegas dengan penyelenggaraan pameran pada 1962 di Balai Wartawan Bandung (PWR) yang dibantu oleh sahabat-sahabatnya, Sanento Yuliman dan Dendi Sudiana. Namun, di kampusnya hal ini menjadi masalah karena pameran mahasiswa harus meminta izin terlebih dahulu dari lembaga.
Padahal pameran ini dibiayai sendiri oleh Jeihan. Dana ini didapatkannya dari kerja keras mengumpulkan sponsor, upah kerja, dan lainlain. Pada dasarnya Jeihan anti terhadap Lekra, namun ia juga tidak mendukung Manikebu. Jeihan berpendapat, bahwa antara kedua pihak itu sama-sama baik. Humanisme Universal dan Realisme Sosialis sebenarnya adalah dua segi tuntutan dari suatu subjek yang sama, yaitu manusia. Humanisme Universal menampilkan kemanusiaan yang universal dan Realisme Sosialis menampilkan aspirasi-aspirasi sosial yang universal (Wawancara dengan Jeihan pada 17 September 2012).

Pada 1963, Jeihan menghasilkan karya yang didominasi dengan warna-warna hitam dan putih. Warna tersebut didasari oleh keadaan ekonomi Jeihan yang serba kekurangan. Selain itu, warna ini mengisyaratkan bentuk ekspresi batin Jeihan yang selalu dalam kegelapan. Kegelapan tersebut adalah bentuk kegelisahan ketika Jeihan sering mengalami perlakuan tidak adil di masa kecilnya, masa kuliahnya yang serba kekurangan dan mendapat perseteruan dari para dosen akibat pemberontakan yang dilakukannya. Kegelisahan yang dialami oleh Jeihan dapat mulai ditegaskan ketika ia menciptakan "mata bolong" pada lukisan figuratifnya. Saat itu, ungkapan mata bolong merupakan gambaran ekspresi kegelapan pada kehidupan Jeihan yang penuh masalah (Sumardjo, 2007: 115).

\section{Fase Penemuan (1965-1975)}

Menurut Ricklefs (2008: 571), periode 1965 terjadi masa-masa kritis tanah air. Jeihan tidak memiliki kepandaian lain kecuali menggambar dan melukis. Ia sama sekali tidak memiliki minat menjadi pegawai yang menjadi bawahan orang lain. Lukisan-lukisan Jeihan yang bersifat seni kurang diperhatikan oleh masyarakat. Jeihan pernah mencoba beralih profesi dengan berjualan ayam goreng, namun percobaan ini gagal. Bukan hanya itu, Jeihan pun berkali-kali dikhianati oleh agen penjualan lukisannya. Realitas sosial yang sulit, semakin menyudutkan Jeihan.

Adanya tekanan kebutuhan keluarga, penipuan dari agen-agen lukisan, menyebabkan Jeihan tersudut. Sekalipun dalam keadaan sulit, 
Jeihan masih tetap berusaha keluar dari keadaan. Jeihan bersikap berani tanpa memikirkan risikonya. Jeihan mulai mempublikasikan lukisan-lukisan "mata bolong”-nya. Melalui Asih (Istri Jeihan), Jeihan menemukan pencerahan batin pada lukisan mata bolongnya. Asih mampu memberikan keteduhan atas segala macam masalah dalam kehidupannya. Karya pertama yang dihasilkan pada "mata bolong" Jeihan bisa dilihat pada karya lukisan dengan judul "Gadis" yang dibuat pada 1965. Lukisan berjudul "Gadis" (Gambar 4) menggambarkan wajah seorang gadis dengan rambut hitam terurai ke sebelah kiri dengan wajah bulat dan kulit cokelat sawo matang (Wawancara dengan Jeihan pada 17 September 2012).

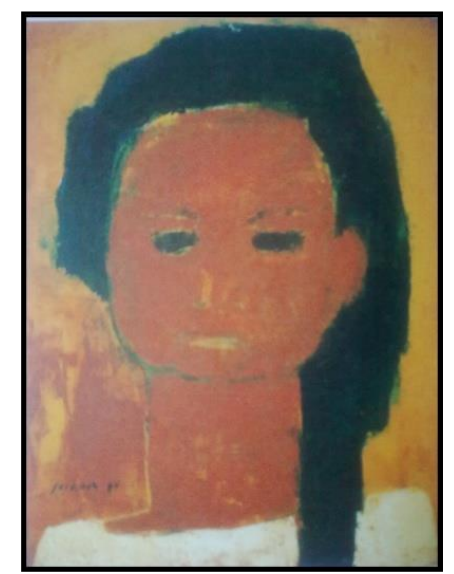

Gambar 4. Lukisan "Gadis”

Sumber: Dokumentasi Peneliti, 2012.

Pada 1966, Jeihan memutuskan keluar dari ITB. Ia keluar sebagai wujud puncak protesnya terhadap dosen-dosen ITB. Di tengah sulitnya perekonomian Jeihan, ia harus membuktikan bahwa ia mampu bertahan dan berhasil dengan prinsipnya kepada dosen-dosen serta pihak-pihak yang mencela karyanya. Pada awalnya, lukisan "mata bolong" Jeihan mengalami kendala. Jeihan dicela oleh beberapa media massa karena lukisannya bermata bolong dan tanpa latar belakang seperti hantu. Mereka berpendapat, jika lukisan tidak bisa membuka mata, maka ingin menjadi apa. Namun, Jeihan tidak patah semangat, ia mengganggap hal itu sebagai tantangan. Akibat celaan dari media massa dan kritikus pada pameran itu, lukisan Jeihan justru banyak terjual. Ia mendapatkan penghasilan yang banyak, dan menghabiskan uang hasil penjualannya dengan berbelanja. Ia seolah-olah ingin membuktikan bahwa ia tidak miskin lagi. Namun, cahaya itu redup kembali, lukisan-lukisan Jeihan belum 'meledak' di pasaran. Kemudian Jeihan mulai berpikir untuk membuat lukisannya agar laku terjual. Ia mempelajari pasar, dan tidak peduli siapa calon pembelinya. Jeihan perlu hidup dari hasil penjualan lukisan-lukisannya. Ia mampu melukis seni, namun percuma saja bila masyarakat yang mempunyai uang tidak minat terhadap lukisannya (Indra TV, 2004: Episode 95).

Tantangan hidupnya dijawab dengan penyelenggaraan pameran tunggal pada tahuntahun berikutnya. Pada 1968 diselenggarakan pameran tunggal di Balai Budaya Jakarta. Kemudian tahun berikutnya (1969) diselenggarakan pameran tunggal di Hadiparana Art Galleryyang juga terletak di Jakarta.

\section{Fase Pematangan (1975-1985)}

Berkat segala usahanya, pada 1975 Jeihan menyelenggarakan pameran tunggal di Centro D'Arte E Cultura di Roma Italia dan Pameran tunggal di Aljazair. Lukisan yang dipamerkan Jeihan masih dalam format sama dengan hasil lukisannya pada 1965. Salah satu lukisan dalam pameran tersebut adalah lukisan "Mbok" dibuat pada 1969 (Kompas, 1980: 6). Lukisan "Mbok" menggambarkan wanita paruh baya yang sedang duduk sendiri dengan latar dan tatapan yang kosong.

Pada 1980-an, ia tampak lebih tertarik melukis karakter wanita mapan, yang memperlihatkan kepribadian dan telah membentuk keyakinan diri. Lukisan perempuan karya Jeihan yang memperlihatkan proses melukisnya dengan karakter tersebut, banyak dipamerkan setelah periode pematangannya, yaitu pada pamerannya di Andy's Gallery pada 29 September sampai 29 Oktober 1993 di Jakarta. Temanya, pekerja wanita dewasa muda yang memperlihatkan kemudaan, atau keremajaan. Pose model dalam karya-karya ini bukan pose yang diatur. Model yang menentukan posenya sendiri, dan rata-rata mengambil pose stereotip seperti pada kalender, sampul majalah, dan foto studio layar. 
Lukisan (Gambar 5) bertema tentang pekerja wanita dapat dilihat dalam lukisan "Susi" yang dibuat pada 1973 (Jeihan, 1993 : 38). Dalam lukisan ini, garis-garis lukisannya terlihat stabil, seperti tidak ada emosi di dalamnya yang biasanya ditandai dengan adanya permainan gradasi warna yang mencolok. Ini menandakan ia lebih dibayangi kondisi kontemplatif dari pada keinginan memburu aspek artistik. Lukisan ini didominasi oleh warna terang, biru muda di atas latar biru tua. Wajah perempuan dalam lukisan ini tidak banyak bercerita. Seperti biasanya memperlihatkan topeng yang dingin. Ia terkesan sedang duduk lurus, diam, sopan, dan wajahnya menatap lurus ke depan. Garis, jejak pisau palet, susunan warna, dan menempatkan aksen, membangun harmoni yang serasi. Namun, dalam lukisan ini Jeihan tidak mengubah penampilan gadis bernama Susi itu. Keartistikan yang digubahnya sama sekali tidak didasarkan oleh idealisasi. Maka lukisan ini, masih memperlihatkan jejak-jejak realitas kontradiksi penampilan dan sikap duduk. Ekspresi Susi tidak hanya memperlihatkan keyakinan, tetapi juga harapan dan kecemasan.

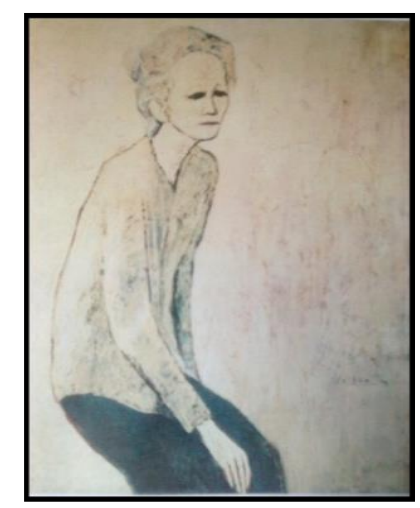

Gambar 5. Lukisan "Mbok"

Sumber: Mamannoor, 2005

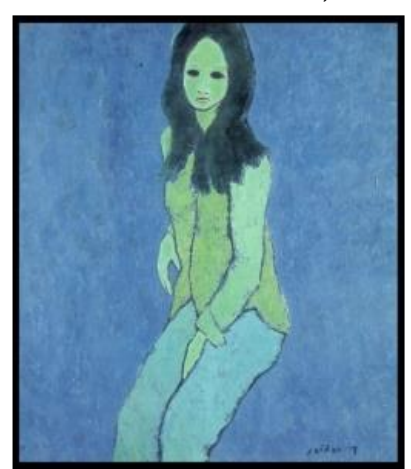

Gambar 6. Lukisan "Susi”

Sumber: Katalog Pameran Andy’s Gallery, 1993.
Dilihat dari penerapannya, pada fase pematangan ini tidak semua lukisan Jeihan, pada 1970-an memperlihatkan kecenderungannya untuk menyusun jejak-jejak pisau palet. Jeihan menampilkan pula ketertarikannya pada reliefrelief Candi Hindu dan Budha. Wujud ketertarikan itu disampaikannya dengan adanya lukisan berjudul "Roro Jonggrang" dibuat pada 1979 yang menggambarkan patung wanita kerajaan dengan delapan tangan dan berlatar kosong yang gelap. Lukisan "Budha, Borobudur" yang dibuat pada 1985 menggambarkan sosok Budha berdiri sendirian dengan kedua tangan di dada menandai rasa mengayomi, sedangkan lukisan "Stupa Borobudur" dibuat pada tahun yang sama. Lukisan ini menggambarkan satu stupa Borobudur dengan siluet patung budha yang duduk di tengahnya berlatar gelap dengan langit berwarna senja dan matahari di antaranya (lihat Gambar 7).

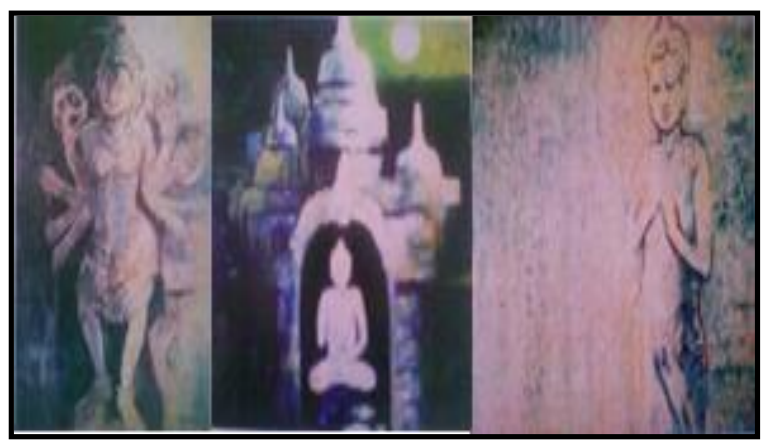

Gambar 7. Lukisan "Roro Jonggrang” (kiri), "Budha, Borobudur" (tengah) dan "Stupa Borobudur" (kanan). Sumber: Mamannoor, 2005 dan Katalog The Soul of Art, Solo Exhibitio", 2012.

Kembali pada karya-karya 1980-an, perkembangan artistik Jeihan mulai terlihat. Artibut dan realitas di sekitar perempuan yang dilukisnya menjadi samar, dan sebagai gantinya muncul pesona perempuan yang lebih mengacu kepada citra artistik. Latar belakang perempuan pada lukisan-lukisan ini sangat tidak nyata, terbungkus garis-garis palet yang terkontrol, warna-warna yang padu, dan perhitungan ruang yang cermat. Dalam kondisi semacam itu, hubungan personal Jeihan dengan model yang dilukisnya terlihat menentukan. Pada karyakaryanya yang berhasil, tercermin keakraban. Realitas ini menunjukkan Jeihan merekap objek 
yang dilukisnya tidak hanya melalui kepekaan melihat, tetapi juga melalui pengenalan dan empati.

Citra perempuan pada lukisan-lukisan Jeihan periode 1980 -an, tercermin pada lukisan berjudul "Palupi" yang dibuat pada 1982 (lihat Gambar 8). Lukisan "Palupi” menggambarkan perempuan bertelanjang dada dan tampak mengenakan rok ilusif. Perempuan pada lukisan ini sedang duduk santai ke arah kanan dengan latar kosong. Perempuan cenderung tampil sebagai kumpulan simbol. Tidak ada atribut dan jejak kenyataan pada perempuan ini. Bahkan tidak dapat dipastikan apakah perempuan ini telanjang atau berbusana. Bagian dadanya yang mengalami penyederhanaan lanjut, mengisyaratkan ketelanjangan. Namun bagian bawah tubuhnya, terlihat hanya sebagai siluet, mengesankan perempuan itu bersarung. Posisi duduk dengan bentuk pinggul membesar mengesankan kesuburan yang identik dengan reproduksi. Namun, tubuh tinggi, punggung membungkuk, memperlihatkan sifat kekar perempuan pekerja. Sementara posisi tangan disandarkan ke pangkuan mengingatkan pada gaya duduk seorang perempuan Jawa yang mencerminkan sifat penyabar dan pengasuh.

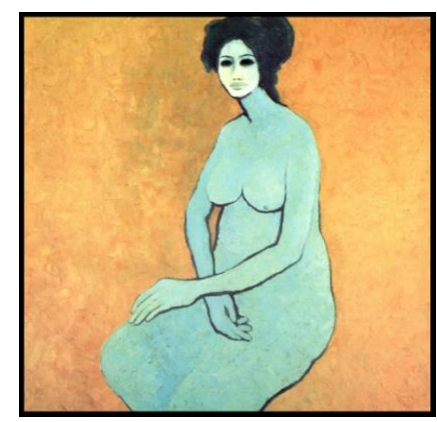

Gambar 8. Lukisan "Palupi"

Sumber: Katalog Pameran Andi’s Gallery, 1993.

Namun ada hal lain dalam lukisan Jeihan episode 1980-an ini. Ketika perempuan dilukiskan tidak dikenal, emosinya tiba-tiba meletup, sapuan kuas terlihat dengan nyata, menampilkan pulasan-pulasan kuas dan gradasi kasar. Lukisan berjudul “Tinah” (Gambar 9) dibuat pada 1985 memperlihatkan kecenderungan itu. Perempuan ini merupakan pemijat tradisional di Solo yang kebetulan berkenalan dengan Jeihan ketika ia mengunjungi kota tempat tinggalnya semasa kecil (Wawancara dengan Jeihan, 17 September 2012).

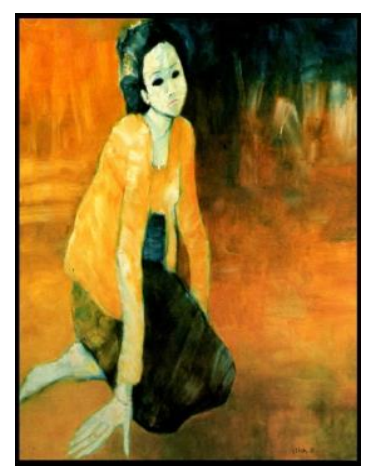

Gambar 9. Lukisan "Tinah"

Sumber: Dokumentasi Peneliti, 2012.

Jejak emosi juga tampak pada lukisan berjudul "Yuli" yang dibuat pada 1983 (tampak pada Gambar 10). Pada lukisan ini ekspresi emosional Jeihan dinyatakannya melalui sayatan pisau palet yang kasar. Lukisan yang memperlihatkan seorang gadis remaja yang masih kekanak-kanakan ini terkategori lukisan Jeihan yang tidak biasa.

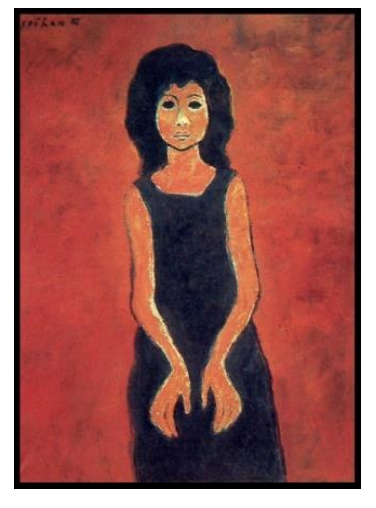

Gambar 10. Lukisan "Yuli"

Sumber: Dokumentas Peneliti, 2012.

Yuli, gadis remaja yang dilukisnya, berada pada posisi simetris, kaku, dan sentral. Pose tubuh dan tangannya mengikuti struktur komposisi kaku serta mengisyaratkan ketegangan wajahnya yang menceminkan rasa takut. Dari bahasan ini, maka terlihat Jeihan menyimpan emosi pada akhir perkembangan 1980-an. Hal ini disebabkan oleh banyaknya kritikus dan seniman yang melecehkan karyakaryanya. Namun Jeihan tetap menunjukkan kualitasnya, hanya mereka yang cerdas pula yang dapat menghargainya. Jeihan berpikir, bahwa 
penjualan lebih penting daripada penilaianpenilaian sumbang (Sumadrjo, 2007: 527).

Pada 4 sampai 11 Agustus 1985, Jeihan mengadakan pameran bersama S. Soedjono dengan tema "Temunya 2 Ekspresionis besar" di Hotel Sari Pasific Jakarta. Pameran ini lebih tercipta suasana "duel" dibanding hanya sebagai pertemuan dua pelukis Indonesia, karena terjadi persaingan harga dan pembeli lukisan. Saat itu, Jeihan mulai diakui sebagai pelukis bernyali besar. Pameran itu oleh banyak pengamat seni rupa diakui sebagai awal mula boom seni lukis Indonesia, karena dua lukisan Jeihan terjual seharga 35.000 dan 50.000 dollar Amerika (saat itu kurs mata uang Rp 1.000 per dollar AS), jika dirupiahkan menjadi $\mathrm{Rp} 35.000 .000$ dan $\mathrm{Rp}$ 50.000.000.

"Mata bolong" dalam lukisannya tidak lagi dikritik sebagai mata hantu, tetapi dikaji ibarat jendela untuk menyelami kedalaman hati. Ada pula yang menyebutkan sebagai keberhasilan Jeihan memadukan mistisisme Timur dengan rasionalisme Barat (Tempo, 2004: 12). Lewat pameran ini, Jeihan disebut sebagai salah satu pelopor dari era booming period di wilayah seni lukis Indonesia. Era ini terjadi pada golongan seni lukis tertentu yang berpusat di daerah Bandung, Jakarta, dan Yogyakarta.

\section{Fase Pemetikan (1986-2012)}

Periode 1986-2012 Jeihan sampai pada titik fase pemetikan. Lukisan Jeihan laku terjual hingga di pasaran internasional seperti Eropa dan Amerika. Penikmat lukisannya mengungkapkan bahwa lukisan Jeihan mempunyai ciri khas Indonesia. Sejak saat itu, karier Jeihan menanjak berkat keteguhan dan kedalamannya (Kompas, 28 Maret 1990).

Hal ini diawali dengan penyelenggaraan sebuah pameran tunggal di Wisma Metropolitan, Jakarta pada 1988. Masa 1990-an dalam pameran-pameran tersebut, lukisan-lukisannya memperlihatkan emosi spontan. Sapuan-sapuan kuas sangat ekspresif semakin nyata. Perubahan lain adalah warna-warnanya menjadi cerah, primer, dan lebih transparan. Citra perempuan dalam lukisan Jeihan era 1990-an juga berubah. Atribut dan realitas perempuan yang dilukisnya, yang hilang pada periode 1980-an, kembali muncul pada lukisan-lukisannya pada masa 1990-an.

Namun perempuan yang dilukisnya pada masa ini tidak lagi terbatas pada perempuan pekerja di kawasan Cicadas, tetapi banyak di antaranya perempuan yang dikenalnya dalam pergaulannya yang semakin luas. Di samping itu, didukung pula dengan kepindahan rumah Jeihan ke daerah Cigadung. Perempuan dalam lukisan ini memperlihatkan kepribadian dan keyakinan diri. Banyak di antaranya tampil dengan wajah frontal. Wajah-wajah ini tidak lagi menyerupai topeng. Sebagai gantinya tampil rona yang terkesan menatap tajam, jauh dari pose mengerling malu-malu.

Lukisan berjudul "Model Yang" (Gambar 11) dibuat pada 1990 adalah contoh jelas. Perempuan pada lukisan ini tegak. Ia berdiri menopangkan kedua tangannya ke sebuah tumpuan ilusif. Posisi ini membuat gesture tubuhnya tidak terbaca. Sebagai gantinya muncul pose yang lurus, formal, dan sedikit terlihat menantang. Wajahnya yang frontal menatap dengan ekspresi yang memperlihatkan keyakinan. Jemarinya dilukiskan lentik, tidak gemulai. Nuansa warna hijau yang membangun suasana redup membuat wajahnya yang menatap tajam tampil menonjol. Tatapan dan ekspresi sama terlihat pada lukisan-lukisan yang berjudul "Nurhayati" (Gambar 12) yang dibuat pada 1993. Perempuan dalam lukisan ini adalah figurfigur metropolitan. Dalam lukisan Jeihan, kepribadian dan keyakinan mereka terpancar tanpa atribut kemoderenan seperti yang biasanya ramai menghiasi sampul majalah perempuan. Pada mereka, sensualitas lagi-lagi tidak menyentuh sensasi seksual.

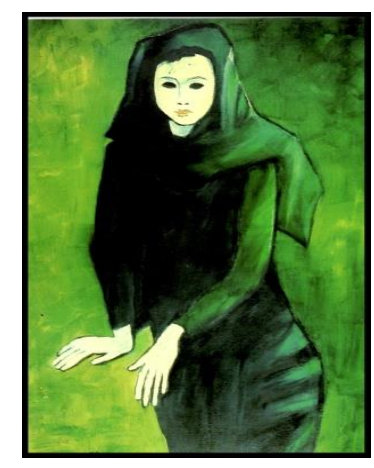

Gambar 11. Lukisan"Model Yang" Sumber: Dokumentasi Peneliti, 2012. 


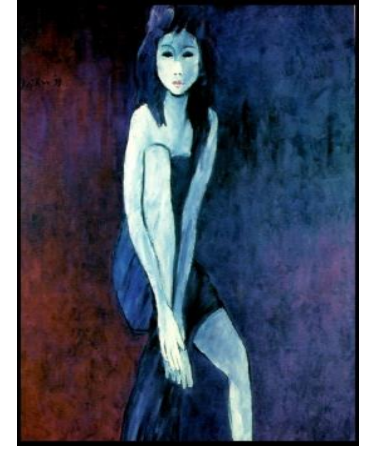

Gambar 12. Lukisan "Nurhayati"

Sumber: Katalog Pameran Andy’s Gallery, 1993)

Jeihan pergi haji pada 1998. Setahun setelahnya, Jeihan membuat lukisan dengan tema haji, dan pada 11 sampai dengan 30 April 1999, Jeihan mengadakan pameran di Galeri Cipta II, Taman Ismail Marzuki, Jakarta, bersama lukisan karya pelukis Hidayat. Jeihan menampilkan dua belas karya yang merupakan hasil perjalanan spiritual Jeihan selama menunaikan ibadah di Tanah Suci. Lukisanlukisan tersebut adalah "Bulan di Atas Ka'bah", "Tawaf", "Sa'i”, "Wukuf di Arafah", "Tafakur di Muzdalifah", "Jumra Aqaba”, "Nafar di Mina”, "Mabit”, "Jabal Rahmah”, "Laut Merah”, “Aku”, dan "Asih Istriku". Lukisan "Bulan di Atas Kabah”, dipasangi harga Rp 3 milyar, dan oleh Museum Rekor Indonesia, lukisan ini dinobatkan sebagai lukisan Indonesia termahal saat itu. Lukisan ini dibuat di atas kanvas berukuran $160 \mathrm{~cm}$ x $140 \mathrm{~cm}$. Dalam lukisan ini, terdapat gambar bulan sabit yang berada tepat di atas ka'bah yang digambarkan berupa garis melintang horisontal di bawahnya berwarna hitam serta ada corak garis-garis berwarna kuning gading yang menandakan ornamen pada ka’bah (tampak pada Gambar 13).

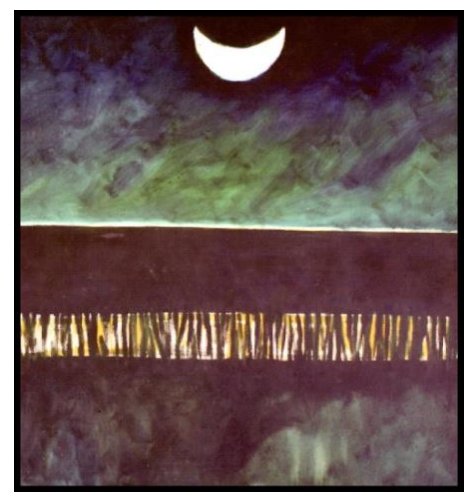

Gambar 13. Lukisan "Bulan di Atas Kabah" Sumber: Dokumentasi Peneliti, 2012.
Dari dua belas lukisan itu, hanya tiga yang dijual. Selain Bulan di Atas Kabah, dua gambar lainnya juga dipasangi harga tinggi, yaitu “Tafakur di Mudzalifah" Rp 2 milyar dan "Wukuf di Arafah Rp 1 milyar” (Gatra, 1999: 16).

Sejak 2000-an Jeihan menyatakan, bahwa ia sangat tertarik pada perempuan yang mandiri, pada wanita yang bisa bertahan dan menembus kesulitan. Seperti yang diungkapkan Jeihan kepada penulis, ia berkata: "Kamu tahu", "perempuan sebetulnya jauh lebih kuat dari pria. Mereka mempunyai kekuatan luar biasa yang tidak bisa dibaca" (Wawancara dengan Jeihan pada 17 September 2012). Perempuan yang dilukiskan oleh Jeihan sebelumnya merupakan perempuan yang memiliki karakter. Karakter yang dimaksud adalah perempuan yang bisa menjadi inspirator, kreator, atau pun sebagai public figure, sedangkan perempuan pada fase sebelumnya lebih menampilkan perempuan lugu, lemah lembut, dan santun (Pikiran Rakyat, $2006: 7)$.

Seperti pada bahasan terdahulu, bahwa ketika tahap kehidupan Jeihan masih pada fase penemuan, perempuan yang dilukisnya sebagian besar adalah perempuan-perempuan yang telah ia kenal, baik tetangga rumahnya, perempuan pekerja, dan perempuan yang memiliki pola pikir tradisi desa. Namun, pada fase ini, Jeihan mulai melukis perempuan yang memiliki pola pikir moderen. Hal ini disebabkan oleh adanya faktor kebatinan Jeihan yang telah stabil. Jiwa pemberontaknya sudah hilang, dan digantikan menjadi jiwa yang lebih menerima. Hidupnya mengutamakan keselarasan dan keseimbangan di segala bentuk, dan dari segi perekonomian ia sudah melewati masa krisisnya. Dengan demikian, Jeihan mendapat kenalan-kenalan baru, suasana baru, dan gaya hidup baru yang menjadikan Jeihan mengenal sosok-sosok perempuan yang memiliki karakter kuat tersebut.

Perempuan ini misalnya, terdapat pada sosok Mimi Rasinah yang merupakan seorang maestro penari topeng Cirebon. Pada 11 Januari 2004, diadakan Pameran Kolaborasi "Jeihan Melukis Rasinah Menari” di Toko You Bandung. Jeihan bertemu dan melukis Rasinah yang sedang menari "Tarian Topeng Kelana". Jeihan 
melukis Mimi Rasinah karena didasari oleh pencitraan karakter dari seorang Mimi Rasinah sebagai penari topeng yang selalu menjunjung kesetiaannya terhadap eksistensi dirinya (Gambar 14). Ia memiliki semangat terhadap apa yang menjadi identitasnya, sepanjang hidupnya, menjalani lakon dengan penuh totalitas. Menurut Jeihan penari topeng yang sedang menari, mencitrakan ekspresi wajah yang tersembunyi dalam topeng tersebut dan tersirat dalam gerakan tangan yang seirama dengan musik (Kompas, 18 Januari 2004: 8).

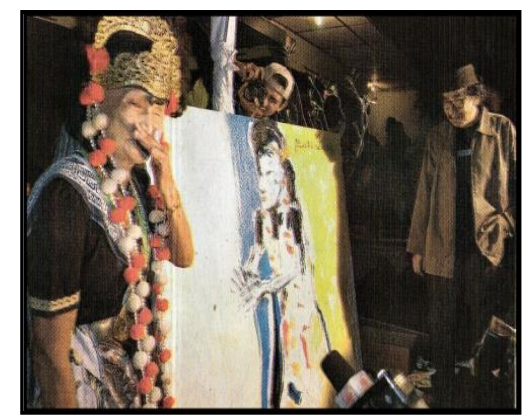

Gambar 14. Mimi Rasinah terharu gembira saat melihat ia dilukis Jeihan

Sumber: Kompas, 18 Januari 2004.

Dengan kata lain, tangan selalu mengikuti pola ekspresi dari raut wajah. Hal ini menambah pemahaman baru bagi Jeihan, sehingga ia merasa perlu untuk melukis Mimi Rasinah sebagai karakter perempuan yang luar biasa.

Contoh lain perempuan berkarakter yang dilukis Jeihan, ada pada lukisan berjudul "Inggrid Kansil" yang dibuat pada 2006. Model dalam lukisan ini adalah Inggrid Kansil yang merupakan seorang artis ibu kota. Selain itu, ia merupakan anggota DPR periode 2009-2014 dari Partai Demokrat untuk Daerah Pemilihan Jawa Barat IV, mewakili daerah Kota Sukabumi dan Kabupaten Sukabumi. Inggrid Kansil digambarkan oleh Jeihan sebagai sosok perempuan Indonesia yang selain cantik, tetapi juga memiliki banyak keahlian serta intelektualitas yang tinggi. (Pikiran Rakyat, 2006: 4). Lukisan ini cukup lama dipajang di Studio Jeihan, dan kemudian dipilih Jeihan untuk dipamerkan pada pameran The Soul of Art, Solo Exhibition yang diselenggarakan pada 28 dan 29 Mei 2012 di Hotel Ritz Carlton Pasific Jakarta (lihat Gambar 15).

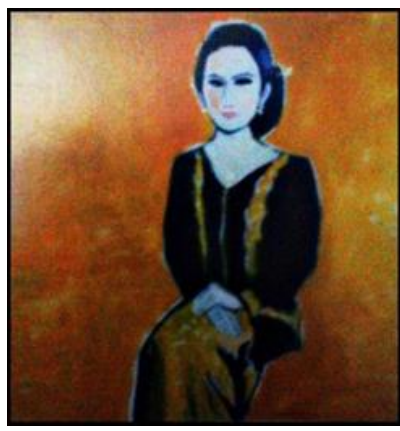

Gambar 15. Lukisan "Inggrid Kansil" Sumber: Katalog The Soul of Art, Solo Exhibition, 2012.

Pameran ini menandakan corak terakhir dalam kajian lukisan Jeihan sepanjang karier sebagai pelukis. Corak tersebut menampilkan lukisan perempuan yang penuh dengan warnawarna yang terang, "mata bolong" yang ditampilkan menyerupai mata yang sedang terpejam. Ekspresi ini menggambarkan sosok perempuan di era globalisasi sekarang ini yang semakin liberal. Perempuan Indonesia bebas berekspresi dan berkarakter sesuai jati dirinya. Representasi perempuan tersebut ditampilkan Jeihan dalam pameran The Soul of Art-nya, yang berarti bahwa kehidupan tidak bisa lepas dari seni. Pameran ini menampilkan seratus lukisan yang dipilih secara matang oleh Jeihan. Lukisan yang ditampilkan adalah karyanya yang dibuat pada 2000-an (Yudono dalam Kompas (online), diunduh pada 3 Maret 2013).

\section{EKSISTENSI LUKISAN MATA BOLONG}

Sebagian besar dari lukisan perempuan Jeihan cenderung berpose murung, duduk terdiam, berbaring, dan melamun. Penggunaan warnanya pun cenderung ke warna-warna gelap. Namun, oleh karena terbentur persoalan ekonomi dan nasib lukisannya yang tidak laku di pasaran, Jeihan menciptakan terobosan-terobosan baru dengan menampilkan sosok perempuan yang memiliki profesi atau keahlian. Jeihan mengikuti pola pasar pada 1970-an berkembang lukisan dengan corak ekspresionis.

Perempuan di lukisannya menjadi lebih ekspresif, misalnya Jeihan banyak membuat lukisan dengan tema penari tradisional Jawa Tengah, Sunda, dan Bali, kemudian ia juga 
membuat lukisan-lukisan perempuan yang sedang memainkan berbagai macam alat musik, atau pun sedang bernyanyi. Unsur misterius yang ada pada lukisannya di awal karier, berangsur-angsur berubah menjadi lukisan yang ceria, lewat dari ekspresi model yang bermacammacam dan gradasi dalam pewarnaan lukisan yang menggunakan warna-warna-warna terang.

Sebagai seniman, Jeihan telah memenuhi kriteria sebagai seniman yang memiliki wawasan dan kepekaan kuat dalam mengomunikasikan serta merepresentasikan karyanya dengan baik. Selain itu, didukung dengan lingkungan pergaulannya yang luas, lukisan Jeihan dilihat dan dinikmati oleh pecinta seni yang menjadi kolektornya. Karena seorang yang tertarik dan ingin memiliki karya seni tentu saja ingin mengenal lebih dekat figur pencipta karya yang diminatinya. Komunitas dan jejaring ini penting untuk memosisikan Jeihan dalam eksistensinya. Maka peran penilaian dari kurator lukisannya secara tidak disadari telah mengangkat lukisannya sehingga diapresiasi oleh publik (Neddy Anto, 2012: 160).

Dalam bidang seni lukis, dunia usaha yang sarat dengan kompetisi pasti menuntut adanya perubahan cara pandang seniman untuk kesediaannya masuk dalam dunia industri kreatif. Hal ini menunjukkan berkembangnya bisnis lukisan di antara pelukis, galeri, dan para pemburu lukisan. Baik pembeli biasa maupun kolektor seni memanfaatkan karya tersebut pada ajang pelelangan di kemudian hari. Selain itu, terdapat pertumbuhan kebutuhan untuk mengisi ruang interior rumah pribadi maupun perkantoran dengan lukisan yang sesuai. Lukisan dapat memenuhi cita rasa rancangan desain interior. Baik ruang mewah maupun gedung moderen dan mahal perlu diisi pula oleh lukisan yang bernilai tinggi. Di sinilah pemasaran dari lukisan Jeihan.

Proses kerja kerasnya diwujudkan dengan adanya pemikiran-pemikiran baru yang disebut sebagai kerja cerdas dalam membaca zaman. Misalnya, dalam lukisan Jeihan fase pemetikan, "mata bolong" yang ada di lukisannya, dibuat mengecil, dan terkadang menyerupai goresan vertikal yang terlihat seperti mata yang hampir tertutup karena sedang mengekspresikan senyuman.

Jeihan rutin mengadakan pameranpameran tunggal, dan pada masa kejayaannya, pengunjung yang datang di pamerannya pun merupakan tokoh-tokoh masyarakat terkenal. Tidak jarang mereka dijadikan model lukisan Jeihan yang langsung ia buat saat pameran itu berlangsung. Ada pula model tokoh masyarakat yang dibuatnya sebelum hari pameran. Misalnya pada saat ia melukis Taufiq Kiemas yang merupakan seorang politikus Indonesia. Lukisan ini dibuat langsung ketika Taufiq Kiemas berkunjung ke pameran Jeihan dengan tema The Soul of Art, Solo Exhibition", pada 28 dan 29 Mei 2012 di Hotel Ritz Carlton Pasific Jakarta. Contoh lain, juga terlihat pada lukisan "Fira" yang modelnya adalah Fira Basuki salah satu penulis novel Indonesia.
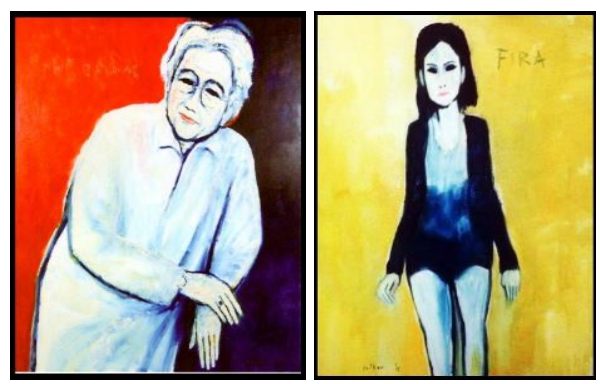

Gambar 16. Lukisan "Taufiq Kiemas" (kiri) dan Lukisan "Fira" (kanan)

Sumber: Katalog The Soul of Art, Solo Exhibition, 2012.

Dengan menjadi pelukis, Jeihan berhasil menempatkan taraf hidupnya selalu menuju yang lebih baik di setiap masanya. Kini Jeihan tinggal menikmati hasil dari kerja kerasnya. Di usia senjanya, Jeihan telah ada di puncak popularitasnya sebagai seniman. Ia dikenal sebagai maestro pelukis Indonesia dengan ciri khas yang kental. Di samping itu, Jeihan juga tetap menjadi pribadi yang sederhana. Jeihan tetap berpenampilan sederhana, dengan mengenakan kaus oblong, celana panjang, sandal santai, dan kopiah yang selalu dikenakannya.

Jeihan tetap Jeihan yang mempunyai kelainan pada otaknya, sering kali ia tetap menderita dengan sakit kepala hebat akibat kecelakaan yang dialaminya semasa kecil. Hal ini dianggap Jeihan sebagai keseimbangan hidup, 
dimana ada kekuasaan atau pun kebahagiaan, di situ juga pasti diberikan kesulitan yang harus diterima dengan ikhlas.

\section{SIMPULAN}

Lukisan Jeihan merupakan hasil dari budaya yang merefleksikan realitas-realitas lingkup kehidupannya yang muncul di dunia seni lukis di Indonesia pada kurun waktu antara 1953 sampai dengan 2012. Berdasar pada "pembacaan" terhadap hasil budaya itu diketahui bahwa problem-problem sensitif pada saat itu banyak didasari oleh kondisi pikiran Jeihan serta masamasa yang mempengaruhi kondisi kariernya sebagai pelukis.

Dengan latar belakang masa kecil Jeihan yang mengalami tekanan-tekanan hingga mempunyai bekal dari pendidikan seni di HBS dan ITB, Jeihan memulai karier kesenimanannya yang berkarakter kuat. Meskipun tempat ia mendapat pendidikan seni mempunyai corak atau aliran seni abstrak yang kebarat-baratan, Jeihan tetap teguh mempertahankan pendiriannya, untuk selalu menjadi diri sendiri, tidak menjadi pengekor atau pun pengikut orang lain. Di tengah kehidupan yang berliku-liku, mendapat celaan dari orang banyak akibat karyanya yang cenderung menyimpang dari pasaran lukisan pada umumnya, yaitu dengan terus membuat lukisan perempuan dengan mata selalu bolong, Jeihan mampu membuktikan, bahwa dirinya bisa bertahan hingga dapat membuahkan hasil yang memuaskan, dengan berhasil menjadi salah seorang pelukis terkaya di Indonesia.

Sebelum menciptakan lukisan, Jeihan mempunyai pola pemikiran, yaitu lukisan figuratifnya dipandang sebagai dzikir yang selalu mengulang-ulang, dan pemaknaan sosok perempuan dalam lukisannya diumpamakan sebagai wayang yang berdiri dalam latar yang kosong. Kedua pola tersebut tidak terlepas dari unsur spiritual dan rasional Jeihan yang selalu seimbang dalam kehidupannya. Misalnya, ketika ia diharuskan melukis "Nude", maka lukisan yang dihasilkan tidak menonjolkan bentuk tubuh yang mempesonakan, melainkan tubuh telanjang yang datar, dan jauh dari kesan pornografi. Hal ini merupakan buah dari proses berfikirnya secara spiritual dan rasional tersebut.

Lukisan-lukisan Jeihan selalu mengusung tema yang konsisten. Namun, ia juga telah berproses dalam membaca zaman, dengan menciptakan tampilan-tampilan baru yang menjadikan lukisan-lukisannya tetap digemari para kolektornya, yaitu membuat variasi pewarnaan, penggunaan model yang bermacammacam karakter, dan unsur gesture yang lebih bervariasi.

Proses kesenimanannya dapat dikategorikan menjadi empat periode. Fase Pencarian (1952-1965) merupakan tahap pembelajaran, Jeihan menemukan format yang pas pada ciri lukisannya. Fase Penemuan (1965-1975) merupakan masa sulit Jeihan dalam kehidupan perekonomiannya, karena lukisannya tidak laku, maka Jeihan berpikir untuk membuat ciri khas dan terobosan baru agar lukisannya dilihat masyarakat, yaitu dengan menciptakan "mata bolong" dan konsisten memakai perempuan sebagai model pada lukisannya. Fase Pematangan pada (1975-1985), Jeihan memantapkan ciri khasnya, dan Fase Pemetikan pada (1986-2012) lukisan Jeihan laku di pasaran dengan harga yang tinggi, hal ini disebabkan oleh adanya era booming period. Jeihan telah mengalami banyak warna-warna kehidupan saat menjalani profesi sebagai pelukis. Dari karier kesenimanannya ini, lukisan Jeihan mempunyai tema-tema yang lekat dengan pemikirannya dan lingkungan sekitar.

Saat ini, ia tinggal menikmati hasil dari kerja cerdasnya selama ini. Jeihan tetap sederhana, hidup dengan serba kecukupan dan bisa menghidupi seluruh keluarganya tanpa menyusahkan anak-anaknya. Kehidupannya telah dijalani secara seimbang. Kehidupan Jeihan memang berubah, tetapi Jeihan sendiri tidak berubah. Ia tetap lebih suka menyendiri, berpenampilan miskin, dan tetap kritis rasional. Hanya saja ia menjadi lebih religius. Ia boleh saja tidak percaya pada teori manusia, tetapi ia tetap percaya pada Allah

\section{REFERENSI}

Anto, Tris Neddy, dkk. (2012). Seri Profesi Industri Kreatif: Menjadi Seniman Rupa. 
Surakarta: Mentagraf, Creative Imprint of Tiga Serangakai.

Film Dokumenter; "Maestro Jeihan" (Jakarta: Indra TV, 17 Januari 2004), episode 95.

Jeihan (1993). Andika: Pameran Lukisan Jeihan Andi's Gallery. Jakara: PT Andi Jaya Abadi.

Yudono, Jodhi "Goresan Figuratif Eksklusif Maestro Lukis Indonesia”, Kompas.com (online)

http://megapolitan.kompas.com /amp/read/2012/05/31/00523817/Gor esan.Figuratif.Eksklusif.Maestro.Lukis.Ind onesia., diunduh pada 3 Maret 2013).

Katalog Pameran Lukisan (2012). "The Soul of Art, Solo Exhibition”. Jakarta: The Soul of Art Foundation.

Ricklefs, M.C. (2008). Sejarah Indonesia Modern 1200-2008 (diterjemahkan oleh Tim Penerjemah Serambi). Jakarta: Serambi Ilmu Semesta.

Mahatma, Masmuni (2010). Bulan di Atas Ka'bah, Sufistika Jeihan. Bandung: Jeihan Institute.

Mamannoor (2005). Jeihan Jeihan Jeihan. Bandung: Yayasan Pengembangan Seni Rupa Indonesia.

Mustika (1993) Tokoh-tokoh Pelukis Indonesia. Jakarta: Dinas Kebudayaan DKI.

Sumardjo, Jakob (2007). Jeihan Ambang Waras dan Gila. Bandung: Jeihan Institute, 2007.

Supangat, Jim (2000). Outlet: Yogya dalam Peta Seni Rupa Kontemporer Indonesia. Yogyakarta: Yayasan Seni Cemeti.

Supartono, Alexander (2000). "Lekra vs Manikebu: Perdebatan Kebudayaan Indonesia 1950-1965” (Skripsi STF Driyarkara Jakarta).

Tambayong, Yapi (2012). 123 Ayat tentang Seni. Bandung: Nuansa Cendekia.

“Sepotong Tangan, Segurat Nasib”, Kompas, 18 Januari 2004.

"Lukisan S. Sudjojono dan Jeihan; Ada Cara Lain untuk Menawarkan”, Kompas, 20 Agustus 1985.

"Himpunan Budaya Surakarta”, Mekar Sari, 15 November 1987.

“Nama \& Peristiwa", Kompas, 28 Maret 1990.

“Tiga Milyar untuk Bulan”, Gatra, 10 April 1999.
Kompas, 1980.

"Mata Perempuan Jeihan, Ah Hantu", Tempo, 24 Januari 2004.

"Pilihannya Perempuan Urban", Pikiran Rakyat, 13 Juli 2006.

\section{DAFTAR INFORMAN}

Wawancara dengan Jeihan Sukmantoro Wawancara dengan Atasi Amin, adik Jeihan. Wawancara dengan Andi, sopir pribadi Jeihan sejak 1980-an. 